\title{
New inhibitors of glucosylceramide synthase and their effect on cell fate
}

\author{
Katarína Turáková ${ }^{1}$, Boris Lakatoš ${ }^{1}$, Andrej Duriš², Daniela Moravčiková², Dušan Berkeš \\ ${ }^{1}$ Department of Biochemistry and Microbiology, Faculty of Chemical and Food Technology, \\ Radlinského 9, 81237 Bratislava, Slovak Republic \\ ${ }^{2}$ Department of Organic Chemistry, Faculty of Chemical and Food Technology, \\ Radlinského 9, 81237 Bratislava, Slovak Republic \\ katarina.turakova@stuba.sk
}

\begin{abstract}
Glucosylceramide (GlcCer) is an essential glycosylated lipid found in organisms ranging from fungi to mammals. It is composed of a hydrophilic $\beta$-linked glucose and a hydrophobic ceramide, with a predominant content of sphingosine in mammals (d18:1). GlcCer is the precursor of a large scale of different glycosphingolipids. This cerebrozide is synthesized from uridine diphosphate-glucose and ceramide by a GlcCer synthase (UDP-glucose:ceramide glucosyltransferase; UGCG, EC 2.4.1.80). GlcCer-based sphingolipids have been identified as important mediators of a variety of cellular functions and their disequilibrium leads to pathological process development and may induce several diseases progression. Therefore, design of UGCG inhibitor represents an important topic for pharmaceutical research. In this paper, we aimed to study effects of newly synthesized derivatives of ( \pm )-threo-1-phenyl-2-palmitoylamino-3-morpholino-1-propanol (PPMP, known UGCG inhibitor) on: i) activity of UGCG in vitro; ii) thymocytes viability; iii) calcium transport through plasma membrane of thymocytes; iv) induction of apoptosis and autophagy in thymocytes. Thymocytes were isolated from thymus of three to seven weeks old mice (ICR strain). The key factors influencing the effect of PPMP analogues were their concentration, chemical structure and incubation time. Derivatives were able to change $\mathrm{Ca}^{2+}$ transport already after 15 min of cultivation, but their effects on cell viability were manifested at least after $12 \mathrm{~h}$ of cultivation. Four from fifteen studied compounds affected UGCG activity after four hour lasting cultivation, - but without correlation with data relating to effects on calcium transport and/or cell viability. Most potent UGCG inhibitor was chosen and applied for induction of apoptosis and autophagy in thymocytes. This inhibitor induced typical DNA fragmentation and upregulation of LC3B protein as autophagy marker, after $2 \mathrm{~h}$ and $4 \mathrm{~h}$ cultivation, respectively.
\end{abstract}

Keywords: Ceramide, glucosyceramide synthase, glycosphingolipids, cell death

\section{Introduction}

Sphingolipids (SLs) are one of the three major classes of membrane lipids in eukaryotic cells. SLs are essential for cellular integrity and play a role in regulating the fluidity of the lipid bilayer. Metabolites of SLs also act as a bioactive messengers and contribute to intracellular signalling through activation and inhibition of different receptors, protein kinases, phosphatases and ion transporters. These metabolites are known to influence numerous cellular functions including growth, differentiation, apoptosis and autophagy (Ryland et al., 2011). The sphingolipid metabolites that either cause mitogenic effects or contribute to regulation of programmed cell death, are each other dynamically balanced. Ceramide and sphingosine are examples of sphingolipids typically associated with cell growth arrest and cell death induction, while glucosylated and phosphorylated sphingolipids including sphingosine-1-phosphate (S1P) are involved in cellular proliferation, survival and drug resistance. Therefore, there is a complex sphingolipid balance that determines fate of the cell. This dynamic equilibrium between ceramide and $\mathrm{S} 1 \mathrm{P}$ was termed "sphingolipid rheostat" (Spiegel, 1999).

In the present paper we focused on ceramide and glucosylceramide (GlcCer) metabolism and functions. Ceramide is a building block of all SLs, it is an important intracellular signalling molecule involved in regulating differentiation, proliferation, and apoptosis (Levy et al., 2010). Ceramide consist of a sphingoid long chain base to which a fatty acid is attached via an amide bond. Ceramide is in the centre of metabolism, and predominantly synthesized by the de novo pathway from serine and palmitoyl$\mathrm{CoA}$ in the endoplasmic reticulum (ER). Ceramide can be produced from sphingomyelin breakdown catalyzed by sphingomyelinases in the inner leaflet of plasma membrane or outer leaflet of lysosome membrane (Gauri et al., 2011). Further metabolism to sphingomyelin and glycosphingolipids occurs in the Golgi apparatus (Futerman et al., 2005), with ceramide being transported from the ER to the Golgi apparatus by either vesicular trafficking or by ceramide transfer protein, CERT (Levy et al., 2010). Complex SLs are divided into three major groups based on the primary residue attached to 
their C1-hydroxy headgroup. This classification also captures the three biosynthetic pathways, spatially separated within ER and Golgi apparatus, that generate many diverse glycosphingolipids and sphingomyelins. The three major enzymes that regulate complex sphingolipid biosynthesis are galactosyltransferase, sphingomyelin synthase and glucosylceramide synthase (Gault et al., 2011).

GlcCer is a fundamental glycosphingolipid found in organisms ranging from mammals to fungi. It is composed of a hydrophilic $\beta$-linked glucose and a hydrophobic ceramide. Mammalian GlcCer mainly contains sphingosine (d18:1), a sphingoid base with one double bond at the $\mathrm{C} 4$ position in a trans conformation, and N-linked C16-C24 fatty acids. The N-acyl chain distribution varies among tissues or cell types mainly due to differences in substrate specificity and expression patterns of ceramide synthases (ceramide synthase 1-6) (Hannun et al., 2011). GlcCer is synthesized by glucosylceramide synthase (UDP-glucose:ceramide glucosyltransferase; UGCG, GlcT-1, CGT, or GCS, EC 2.4.1.80) from ceramide and UDP-glucose. Enzymatic activity of GCS is activated after binding a reticulon family protein: c-Fos protein and RTN-1C (Marks et al., 1999). These binding partners, however, are not essential for GCS activity, because human GCS expressed in Escherichia coli is active (Ichikawa et al., 1996). GCS is a type III membrane protein that contains a single putative transmembrane domain at its $\mathrm{N}$ terminus, with its $\mathrm{C}$ terminus located in the cytosolic face of Golgi apparatus (Marks et al., 1999). The active site of this enzyme faces to cytosol, thus, GlcCer is synthesized on the cytosolic surface of the Golgi apparatus (Ishibashi et al., 2013).

Present paper is dealing with characterisation of panel newly synthesized ( \pm )-threo-1-phenyl-2palmitoylamino-3-morpholino-1-propanol (PPMP, known UGCG inhibitor) derivatives on GCS activity, $\mathrm{Ca}^{2+}$ transport through plasma membrane, apoptotic DNA fragmentation and LC3 protein as autophagy marker expression. Freshly isolated mouse thymocytes were used as cell model.

\section{Experimental}

\section{Materials and methods \\ Reagents}

The reagents were purchased as follows: Fluo-3-AM from Invitrogen (Eugen, OR, USA), N-[12-[(7nitro-2-1,3-benzoxadiazol-4-yl)amino]dodecanoyl]D-erythro-sphingosine (NBD-C12-ceramide) from Avanti Polar Lipids (Alabaster, AL, USA), HPTLG silica gel $\mathrm{F}_{254}$ plates from Merck KGaA (Darmstadt, Germany), rapamycin, 1-phenyl-2-palmytoylamino3-morpholino-1-propanol (PPMP), primary anti- bodies anti-actin and anti-LC3B, secondary antibody anti-rabbit IgG and chemiluminescent peroxidise substrate-3 from Sigma-Aldrich (St. Louis, MO, USA), annexin-V-FLUOS from Roche Diagnostics GmbH (Mannheim, Germany), mammalian protein extraction reagent "SoluLyse-M" from Genlatis (San Diego, CA, USA), derivatives of PPMP (Tab. 1.) were synthesized at Department of Organic Chemistry, Faculty of Chemical and Food Technology.

Tab. 1. Newly synthesized derivatives of PPMP used in this work.

\begin{tabular}{llc}
\hline Derivative & Formula & $\begin{array}{c}\text { Molecular weight } \\
\text { (g/mol) }\end{array}$ \\
\hline AD632 & $\mathrm{C}_{24} \mathrm{H}_{46} \mathrm{~N}_{2} \mathrm{O}_{3}$ & 394.63 \\
AD648 & $\mathrm{C}_{27} \mathrm{H}_{46} \mathrm{~N}_{2} \mathrm{O}_{3}$ & 446.67 \\
AD679 & $\mathrm{C}_{27} \mathrm{H}_{46} \mathrm{~N}_{2} \mathrm{O}_{2}$ & 430.67 \\
AD710 & $\mathrm{C}_{24} \mathrm{H}_{40} \mathrm{~N}_{2} \mathrm{O}_{3}$ & 404.59 \\
AD724 & $\mathrm{C}_{26} \mathrm{H}_{44} \mathrm{~N}_{2} \mathrm{O}_{3}$ & 432.64 \\
AD725 & $\mathrm{C}_{28} \mathrm{H}_{48} \mathrm{~N}_{2} \mathrm{O}_{3}$ & 460.69 \\
AD732 & $\mathrm{C}_{24} \mathrm{H}_{40} \mathrm{~N}_{2} \mathrm{O}_{3}$ & 404.59 \\
AD733 & $\mathrm{C}_{24} \mathrm{H}_{40} \mathrm{~N}_{2} \mathrm{O}_{3}$ & 404.59 \\
KC54 & $\mathrm{C}_{26} \mathrm{H}_{44} \mathrm{~N}_{2} \mathrm{O}_{3}$ & 432.64 \\
KC75 & $\mathrm{C}_{27} \mathrm{H}_{46} \mathrm{~N}_{2} \mathrm{O}_{4}$ & 462.67 \\
DM-744 & $\mathrm{C}_{24} \mathrm{H}_{39} \mathrm{NO}_{4}$ & 405.57 \\
DM-754 & $\mathrm{C}_{23} \mathrm{H}_{37} \mathrm{NO}_{3}$ & 375.54 \\
DM-PhSoxOH & $\mathrm{C}_{21} \mathrm{H}_{31} \mathrm{NO}_{4}$ & 361.48 \\
DM-PhAoxOH & $\mathrm{C}_{23} \mathrm{H}_{35} \mathrm{NO}_{4}$ & 389.53 \\
DM-TolSoxOH & $\mathrm{C}_{22} \mathrm{H}_{33} \mathrm{NO}_{4}$ & 375.50 \\
\hline
\end{tabular}

\section{Cell model}

Thymocytes from three to seven weeks-old mice (ICR strain) $\left(0.5 ; 1 ; 3.5 ; 5 ; 10 ; 30 \times 10^{6}\right.$ cells/ $\left.500 \mu \mathrm{l}\right)$ were cultured at $37^{\circ} \mathrm{C}$ in $5 \% \mathrm{CO}_{2}$ in RPMI 1640 medium containing $10 \%$ fetal bovine serum (FBS). Cell viability was controlled by using the Trypan blue exclusion method.

\section{Calcium transport measurements}

Thymocytes $\left(5 \times 10^{6}\right.$ cells $)$ were incubated with PPMP and derivatives for $15 \mathrm{~min}$ and $12 \mathrm{~h}$ at $37^{\circ} \mathrm{C}$. Changes of calcium transport were measured using $\mathrm{Ca}^{2+}$ sensitive probe Fluo-3 on spectrofluorometer FluoroMax-4 (Horiba Jobin Yvon, Edison, NJ, USA) for $900 \mathrm{~s}$ after addition of $\mathrm{Ca}^{2+}$ (final concentration $2.5 \mathrm{mmol} / \mathrm{l})$.

\section{Cellular ceramide glycosylation assay}

Thymocytes $\left(3.5 \times 10^{6}\right.$ cells/well $)$ were treated with PPMP and new derivatives (fin. conc. $1 \mu \mathrm{mol} / \mathrm{l}$ and $10 \mu \mathrm{mol} / \mathrm{l})$ for $2 \mathrm{~h}$ in 24 -well plates with $10 \% \mathrm{FBS}$ RPMI-1640 medium at $37^{\circ} \mathrm{C}$. Cells were switched to $500 \mu \mathrm{l}$ of $1 \% \mathrm{BSA}$ RPMI medium containing 
$100 \mu \mathrm{mol} / 1$ NBD C12-Cer complexed with BSA. After $2 \mathrm{~h}$ incubation at $37^{\circ} \mathrm{C}$, cells were then rinsed twice with PBS ( $\mathrm{pH} 7.4$ ), scraped with $400 \mu$ l of ice-cold acidic methanol (acidic acid: methanol, $1: 50, \mathrm{v} / \mathrm{v})$. Lipids were extracted by the addition of chloroform $(400 \mu \mathrm{l})$ and water $(400 \mu \mathrm{l})$. After centrifugation ( $5 \mathrm{~min}, 10000 \mathrm{rpm}$ ), the organic lower-phase was collected into new tubes. Lipids were re-extracted by addition of chloroform $(500 \mu \mathrm{l})$ and centrifuged (5 min, $10000 \mathrm{rpm}$ ). The organic lower-phase was pooled together and evaporated using by vacuum evaporator, and resuspended in $100 \mu \mathrm{l}$ of chloroform/methanol (1:1, v/v). Samples $(30 \mu \mathrm{l})$ were applied to HPTLC plates. The samples were resolved using chloroform/ methanol/ $20 \%$ ammonia (70: 30: 6.25, v/v/v). HPTLC plates were analyzed using phosphoimager Thyphoon 9210 (Amersham Biosciences, Piscataway, NJ, USA).

Detection of apoptosis and necrosis in thymocytes

Cells $\left(0.5 \times 10^{6} /\right.$ well $)$ were cultured in presence of PPMP and derivatives (fin. conc. $1 \mu \mathrm{mol} / \mathrm{l}$, $10 \mu \mathrm{mol} / \mathrm{l}$ ) for 2, 6, 12 and 24 hours under standard culture conditions. After this incubation period, the proportion of apoptotic and necrotic cells was detected using an annexin V/ propidium iodide kit (Calbiochem, USA). According to the previously described protocol (Barancik et al., 2012), the cells were washed twice with PBS and gently resuspended in binding buffer containing $0.5 \mu \mathrm{g} / \mathrm{ml} \mathrm{FITC-}$ labeled annexin-V. The mixtures were incubated for $15 \mathrm{~min}$ at room temperature in the dark and then centrifuged (15 min, $2500 \mathrm{rpm}$ ). The resulting sediments were resuspended in binding buffer, and propidium iodide (final concentration $0.6 \mu \mathrm{g} / \mathrm{ml}$ ) was added to each sample and than were analyzed by flow cytometry using an Accuri C6 flow cytometer (BD Bioscience, USA).

\section{Estimation of apoptotic DNA fragmentation}

Thymocytes $\left(10 \times 10^{6} /\right.$ well $)$ were incubated for 4,8 , 12 and $24 \mathrm{~h}$ in presence of derivative AD648 (final concentration $10 \mathrm{nmol} / 1,100 \mathrm{nmol} / 1,1 \mu \mathrm{mol} / \mathrm{l}$, $10 \mu \mathrm{mol} / \mathrm{l})$ and cis-Pt $(25 \mu \mathrm{mol} / \mathrm{l})$. After incubation, thymocytes suspensions were centrifuged at $4{ }^{\circ} \mathrm{C}$ (5 min, $2700 \mathrm{rpm}$ ) and lysed in $10 \mathrm{mmol} / 1$ Tris- $\mathrm{HCl}$ (pH 7.4), $0.2 \%$ Triton X-100, $100 \mu \mathrm{g} / \mathrm{ml}$ proteinase $\mathrm{K}$, and $1 \mathrm{mmol} / \mathrm{l} \mathrm{EDTA}$ for $10 \mathrm{~min}$ on ice and for $60 \mathrm{~min}$ at room temperature. After centrifugation at $4{ }^{\circ} \mathrm{C}$ (30 $\left.\mathrm{min}, 13900 \mathrm{rpm}\right)$, DNA was precipitated overnight at $-20^{\circ} \mathrm{C}$ in ethanol and $0.3 \mathrm{~mol} / 1 \mathrm{Na}$ acetate, and centrifuged (30 $\mathrm{min}, 13900 \mathrm{rpm} ; 4^{\circ} \mathrm{C}$ ). The pellet was incubated for $30 \mathrm{~min}$ at $37^{\circ} \mathrm{C}$ with $50 \mu \mathrm{g} / \mathrm{ml}$ DNase-free RNase. DNA was quantified by UV spectrometry at $260 \mathrm{~nm}$. Approximately
$5 \mu \mathrm{g}$ of DNA, mixed with gel-loading solution, was incubated for $5 \mathrm{~min}$ at $65^{\circ} \mathrm{C}$, run on a $1.5 \%$ agarose gel containing ethidium bromide, and visualized by transilumination with UV light (Lépine et al., 2004).

\section{Western blot analysis}

Cells $\left(30 \times 10^{6} /\right.$ well $)$ were incubated with AD648 (1 $\mu \mathrm{mol} / \mathrm{l}, 10 \mu \mathrm{mol} / \mathrm{l})$, rapamycin $(50 \mathrm{nmol} / \mathrm{l})$, glucose $(10 \mathrm{mmol} / \mathrm{l})$ and RPMI-1640 medium without FBS for 2, 4, 8 and 12 h. After incubation, thymocytes were washed three times in ice-cold PBS and lysed by addition of $200 \mu \mathrm{l}$ of SoluLyse-M to each sample. Samples were gently shaked $10 \mathrm{~min}$ at room temperature. Cell debris was removed by centrifugation (15 min, $6700 \mathrm{rpm}$ ). Proteins in the supernatant were separated by SDS-PAGE on $12 \%$ gels and transferred onto polyvinylidene difluoride membranes. After incubation with primary and secondary antibodies, proteins were visualizes by ECL (Lépine et al., 2004).

\section{Results and discussion}

Effects of newly synthesized PPMP derivatives were dependent on their chemical structure and duration of cell cultivation. Several analogues had a significant inhibitory effect on calcium transport, while some operated slightly stimulating and some were without effect even after prolonged exposure. It may be caused by different distribution of cells underlying processes of maturation to T-cells. This is supported by results obtained from a flow cytometry. We observed subpopulations of thymocytes that differed in size (data not shown). The most significant inhibitory effect after $15 \mathrm{~min}$ preincubation was due to the action of derivatives AD679 (final concentration $100 \mathrm{nmol} / \mathrm{l}$, Fig. 1A) and KC75 (final concentration $10 \mathrm{nmol} / \mathrm{l}$, Fig. 1B), and DM-744 (final concentrations $10 \mathrm{nmol} / \mathrm{l}$, $1 \mu \mathrm{mol} / \mathrm{l}$ and $10 \mu \mathrm{mol} / \mathrm{l}$, Fig. 1C). The similar effect was observed by using well known inhibitor of UGCG PPMP (Fig. 1D).

Activity of UGCG was affected by 4 from 16 studied compounds, but without correlation with changes in calcium transport and cell viability. The most significant inhibitory effect, about $50 \%$, has PPMP (final concentration $10 \mu \mathrm{mol} / \mathrm{l})$. Other derivatives, AD648, AD 679, AD725 (final concentration $10 \mu \mathrm{mol} / \mathrm{l}$ ) and AD733 (final concentration $1 \mu \mathrm{mol} / \mathrm{l}$ ) decreased the activity of UGCS from $17 \%$ to $28 \%$ compared to control (Fig. 2B). Interestingly, derivative AD648 has a biphasic effect on activity of UGCG. Its addition to final concentration of $1 \mu \mathrm{mol} / 1 \mathrm{had}$ a significant stimulatory effect, whereas higher concentration provoked inhibition of enzymatic activity. Simi- 
A

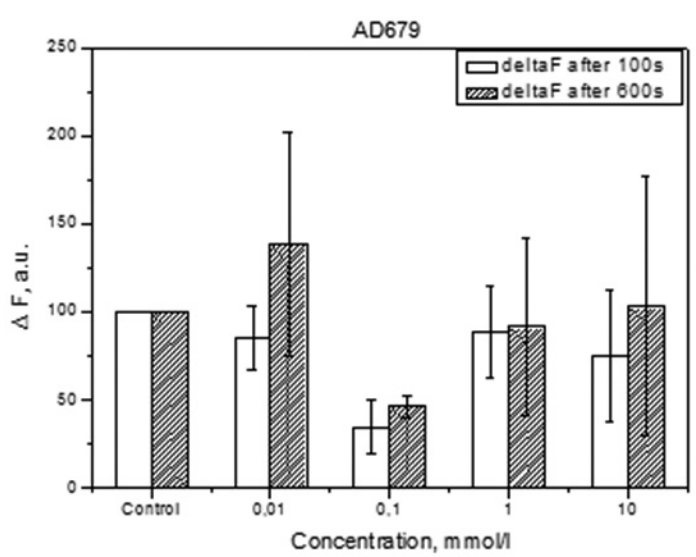

C

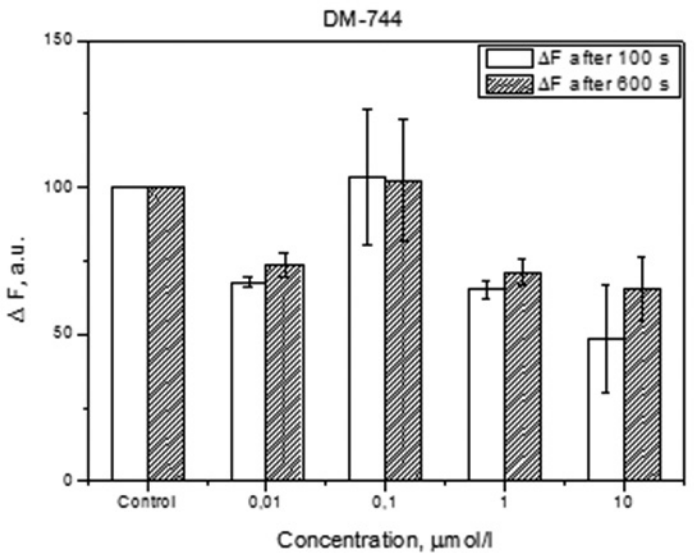

B

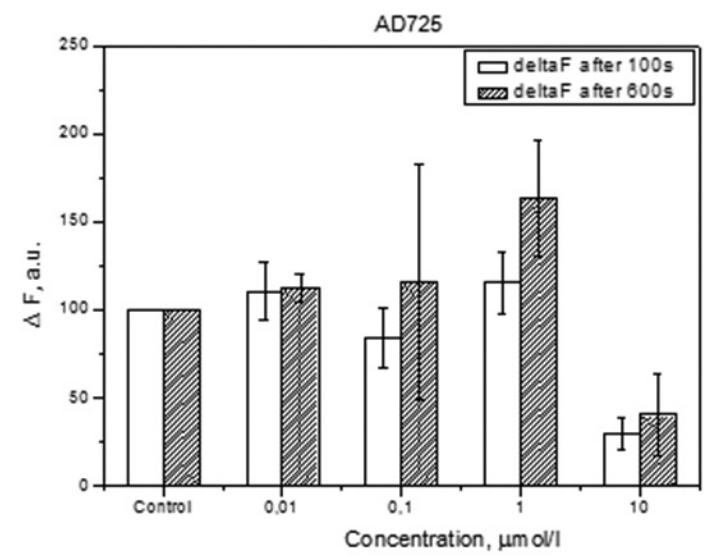

D

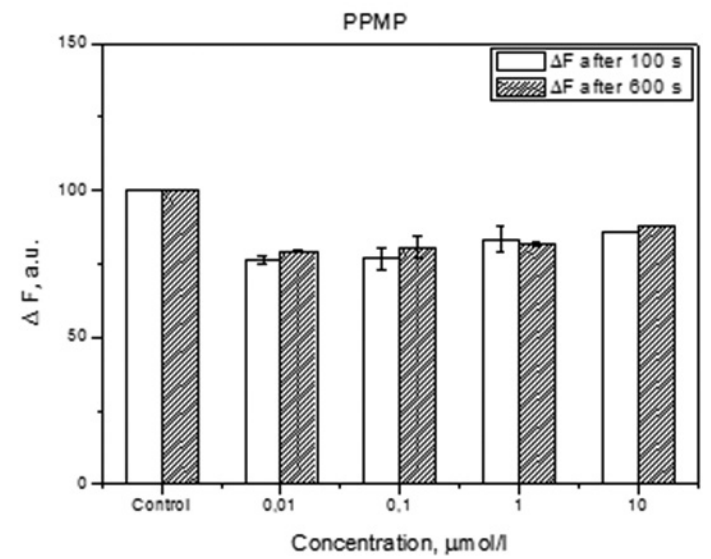

Fig. 1. Changes in calcium transport measured as FLUO-3 fluorescence. Graphs represents changes in fluorescence after addition of $\mathrm{Ca}^{2+}$ (final concentration $2.5 \mathrm{mmol} / \mathrm{l}$ ) in $100 \mathrm{~s}$ and $600 \mathrm{~s}$.

Upper panels - cells preincubated with derivatives AD679 (A) and AD725 (B) for 15 min at $37^{\circ} \mathrm{C}$.

Lower panels - cells incubated in presence of DM-744 (C) and PPMP (D) $12 \mathrm{~h}$ in humidified atmosphere containing $5 \% \mathrm{CO}_{2}$ at $37^{\circ} \mathrm{C}$. Results represent mean $\pm \mathrm{SD}$ of 2 independent measurements.

larly, biphasic effect was also observed for PPMP and AD725.

No significant changes were observed in viability of thymocytes after 2 and $6 \mathrm{~h}$ of cultivation (under standard conditions) with studied compounds measured with propidium iodide by flow cytometry. But, their effect was manifested after 12 and $24 \mathrm{~h}$ of cultivation. The highest level of apoptotic cells measured by annexin-V binding was caused by derivative AD632 (final concentration $10 \mu \mathrm{mol} / \mathrm{l}$ ). However, the level of necrotic cells was not affected comparing to control measurement. In contrast, DM-744 (final concentration $10 \mu \mathrm{mol} / \mathrm{l}$ ) generated the highest amount of necrotic cells (data not shown).

We decided to study the induction of apoptosis and autophagy by derivative AD648 because of its biphasic effect on UGCG activity. Several cultivation times were tested $(4,8,12$ and $24 \mathrm{~h})$. The typical DNA fragments were only observed after $4 \mathrm{~h}$ cultivation of thymocytes with AD648 at final concentration of
$10 \mu \mathrm{mol} / \mathrm{l}$. AD648 at concentration $1 \mu \mathrm{mol} / \mathrm{l}$ that is stimulating UGCG activity, induced DNA fragments formation after prolonged incubation.

LC3 is an ubiquitin-like protein that becomes anchored and tightly associated with the autophagosomal membranes. LC3 proteins are specifically cleaved at their carboxyl termini to form LC3-I, which has an exposed carboxy-terminal glycine that is conjugated to phosphatidylethanolamine to form LC3-II. These membrane proteins serve as autophagic markers (Hansen et al., 2011) as the ratio between LC3B-I and LC3B-II correlate with changes in autophagy (Klionsky et al., 2012). Using the anti-LC3B antibody the process of autophagy was studied. It occurred after $4 \mathrm{~h}$ cultivation independently on the AD648 concentration (Fig. 4B).

\section{Conclusions}

The effects of new inhibitors of glucosylceramide synthase were dependent on their chemical struc- 

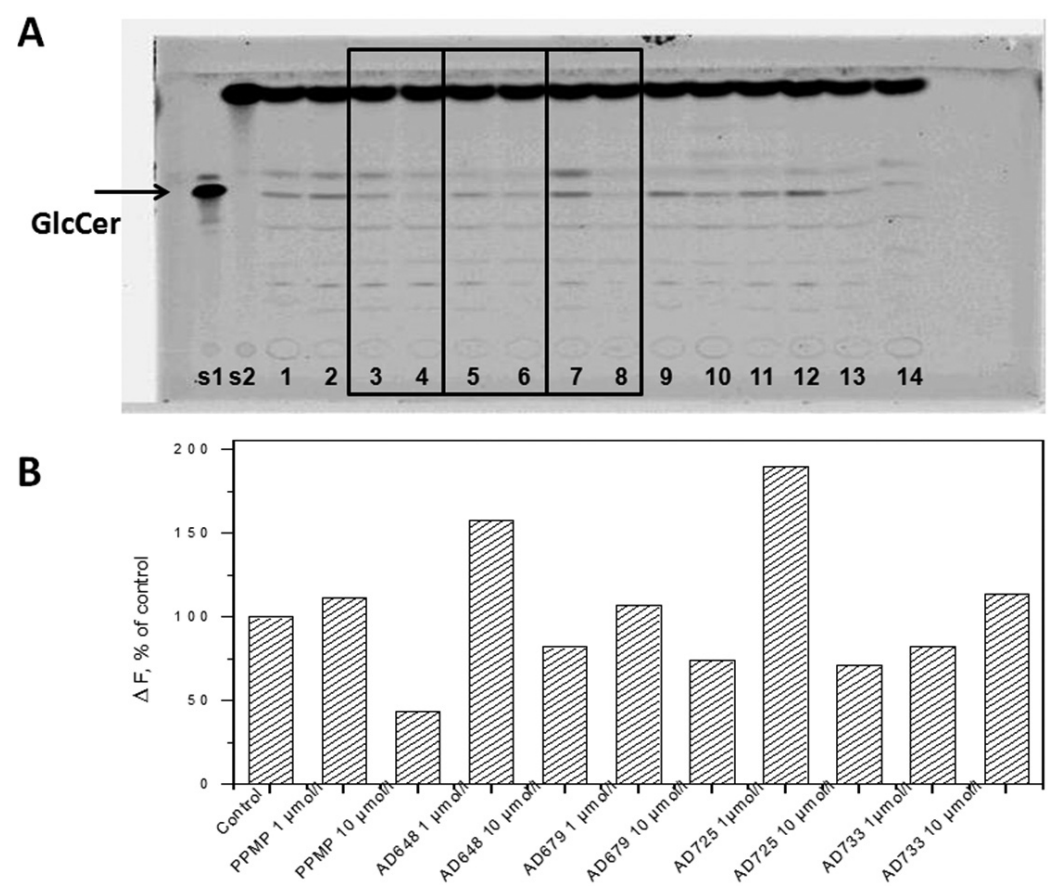

Fig. 2. Changes in UGCG activity after treatment of cells with PPMP and several new derivatives. Biphasic effect of PPMP (A, line 3 fin. conc. $1 \mu \mathrm{mol} / \mathrm{l}$, line 4 fin. conc. $10 \mu \mathrm{mol} / \mathrm{l}$ ),

AD648 (A, line 5 fin. conc. $1 \mu \mathrm{mol} / \mathrm{l}$, line 6 fin. conc. $10 \mu \mathrm{mol} / \mathrm{l}$ ) and AD725 (A, line $71 \mu \mathrm{mol} / \mathrm{l}$, line $810 \mu \mathrm{mol} / \mathrm{l})$ is framed on fluorescence-analyzed HPTLC plate. Graphical representation of fluorescent analysis of HPTLC plate. Thymocytes were cultivated $2 \mathrm{~h}$ with compounds in humidified atmosphere containing $5 \% \mathrm{CO}_{2}$ at $37^{\circ} \mathrm{C}(\mathrm{B})$.

Fig. 3. Typical DNA fragments. Thymocytes were cultivated with AD648 final concentration $1 \mu \mathrm{mol} / \mathrm{l}$ and $10 \mu \mathrm{mol} / \mathrm{l}$ for 4 hours (A), 8 hours (B), 12 hours (C) and for 24 hours (D) in humidified atmosphere containing $5 \% \mathrm{CO}_{2}$ at $37^{\circ} \mathrm{C}$.

ture and duration of cell cultivation. Several derivatives were able to change $\mathrm{Ca}^{2+}$ transport already after 15 minutes of cultivation, but their effect of cell viability manifested only after 12 hours of cultivation. Activity of UGCG was affected in case of 4 from 16 studied compounds after longer cultivation, but was not in relation with changes in calcium transport and cell viability. The obtained results suggest the newly synthesized derivate AD648 could be
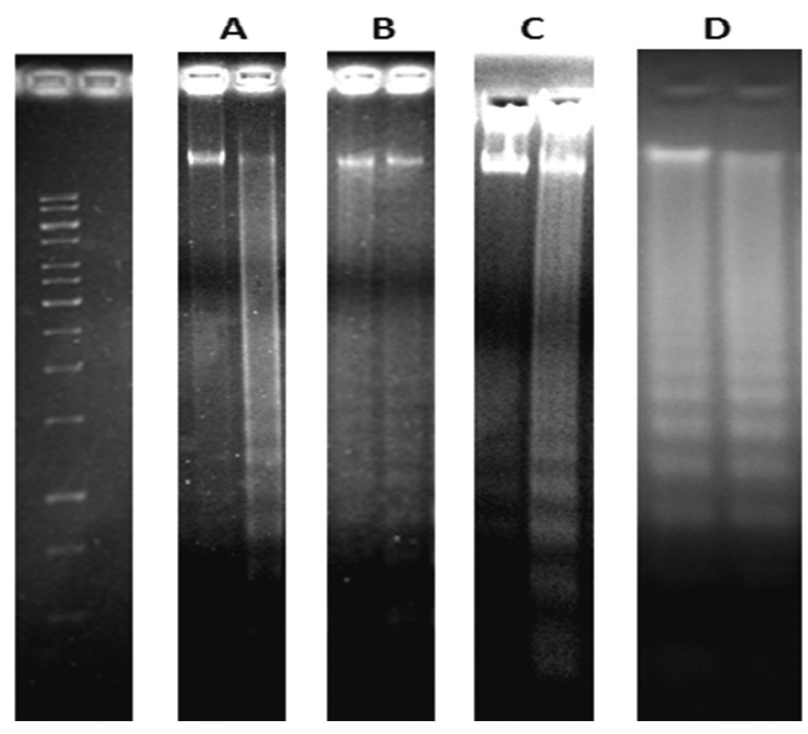

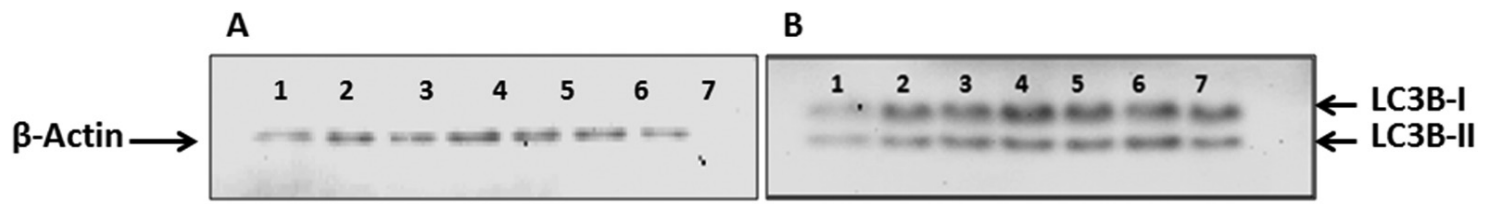

Fig. 4. Detection of $\beta$-actin and LC3B proteins in thymocytes. Cells were treated with compounds $4 \mathrm{~h}$ at humidified atmosphere containing $5 \%$ of $\mathrm{CO}_{2}$ at $37^{\circ} \mathrm{C}$. $\beta$-actin $(42 \mathrm{kDa})$ proteins are at the panel A. LC3B

(LC3B-I (18kDa) and (LC3B-II (16 kDa)) proteins are at the panel B. 1 - control, 2 - control + DMSO,

3 - thymocytes cultivated without fetal bovine serum (10\%), 4 - rapamycin (fin. conc. $50 \mathrm{nmol} / \mathrm{l}$ ),

5 - AD648 (fin. conc. $1 \mu \mathrm{mol} / \mathrm{l}$ ), 6 - AD648 (fin. conc. $10 \mu \mathrm{mol} / \mathrm{l}$ ), 7 - glucose (fin. conc. $10 \mathrm{nmol} / \mathrm{l}$ ). 
considered as the time and concentration dependent biphasic effector. Its action leads to combined cell death, inducing both autophagy and apoptosis specific features.

\section{Acknowledgement}

This work was supported by grant agencies VEGA 1/0471/11, VEGA 1/0441/11 and APVV-0719-12.

\section{References}

Barancik M, Bohacova V, Gibalova L, Sedlak J, Sulova Z, Breier A (2012) Int J Mol Sci 13: 369-382.

Futerman AH, Riezman H (2005) Trends Cell Biol 15: 312-318.

Gault CR, Obeid LM, Hannun YA (2010) Adv Exp Med Biol 688: 1-23.

Hannun YA, Obeid LM (2011) J Biol Chem 286: 2785527862.

Hansen TE, Johansen T (2011) BMS Biology 9:39, 1-4.

Ichikawa S, Sakiyama H, Suzuki G, Hidari KI, Hirabayashi Y (1996) Proc Natl Acad Sci USA 93: 4638-4643.
Ishibashi Y, Kohyama-Koganeya A, Hirabayashi Y (2013) Biochim Biophys Acta 1831: 1475-1485.

Klionsky DJ, Abdalla FC, Abeliovich H, Abraham RT, Acevedo-Arozena A et al. (2012) Autophagy 8:4, 445-544.

Lépine S, Lakatoš B, Courageot M-P, Le Stunff H, Sulpice J-C, Giraud F (2004) J Immunol 173: 3783-3790.

Levy M, Futerman AH (2010) IUBMB Life 62(5): $347-356$.

Marks DL, Wu K, Paul P, Kamisaka Y, Watanabe R, Pagano RE (1999) J Biol Chem 274: 451-456.

Patwardhan GA, Liu YY (2011) Prog Lipid Res 50(1): 104-114.

Ryland LK, Fox TE, Liu X, Loughran TP, Kester M (2011) Cancer Biol Ther 11:2 138-149.

Spiegel S (1999) J Leukoc Biol 65: 341-344.

Wu K, Marks DL, Watanabe R, Paul P, Rajan N, Pagano RE (1999) Biochem J 395-400.

Xie P, Shen Y-F, Shi Y-P, Ge S-M, Gu Z-H, Wang J, Mu H-J, Zhang B, Qiao W-Z, Xie K-M (2008) Leukemia Res 32: 475-480. 